\title{
A PRODUÇÃo DE MEMÓRIA BIOTECNOLÓGICA E SUAS CONSEQÜÊNCIAS CULTURAIS
}

\section{Jonatas Ferreira}

\begin{abstract}
E o rei replicou: "Incomparável mestre em artes, ob Theuth (O tekhnikótatú Theúth), uma coisa é

o homem capaz de trazer à luz a fundação de uma arte, outra aquele que é capaz de apreciar o que esta arte comporta de prejuizo ou utilidade para os homens que deverão fazer uso dela. Neste momento, eis que em tua qualidade de pai dos caracteres da escrita (patér òn grammáton), atribuiste-lhes, por complacência para com eles, todo o contrário (tounatíon) de seus verdadeiros efeitos! Pois este conhecimento terá, como resultado, naqueles que o terão adquirido, tornar suas almas esquecidas uma vez que cessarão de exercer sua memória [...] Não é, pois, para a memória, mas para a rememoração que tu descobriste um remédio (oúkoun mnémes, allà hupomnéseos, phármakon heûres). Quanto à instrução (Sophías dè), é a aparência (dóxan) dela que ofereces a teus alunos, e não a realidade (alétheian).
\end{abstract}

Artigo recebido em març/2003

Aprovado em julbo/2003 quando, com efeito, com tua ajuda, eles transbordarem de conbecimentos sem terem recebido ensinamento, parecerão bons para julgar muitas coisas, quando, na maior parte do tempo, estarão privados de todo julgamento; e serão, além disso,

insuportáveis, já que terão a aparência de bomens instruídos (doxóphoi) em vez de serem homens instruídos (anti sophôn)"!

Fedro, 274 e 275b, apud Derrida, 1997, p. 49.

\section{Introdução}

Um dos traços políticos distintivos do mundo moderno parece ser a transformação da vida natural em espaço de exercício de poder. Ao desnudar o corpo de significados culturais específicos, passando a apreciá-lo segundo critérios de funcionalidade e operacionalidade, a ciência finda por trazer a vida biológica para o centro da 
cena política industrial. Assim, o corpo "para a sensibilidade moderna parece tão fechado, autárquico e fora do reinado do significado" (Laqueur, 2001, p. 18). Esta linha de argumento é bem conhecida dos leitores de Foucault. Sugiro, todavia, a necessidade de se perceber nos desenvolvimentos recentes da biotecnologia molecular algo qualitativamente diferenciado daquilo que Foucault chamou biopoder. Embora partindo de uma politização da vida biológica, da "vida nua", as dinâmicas políticas que se abrem ao capitalismo contemporâneo já não se definem primordialmente por meio do privilégio à inteireza do corpo individual ou aos limites entre as espécies. Isso é um dado de partida importante. Para usar o jargão adequado, o biopoder já não pode ser plenamente compreendido como "disciplina" nem como "regulamentação". A inteireza dos corpos, condição de um controle científico de sua plasticidade, assim como os limites entre as espécies, por meio dos quais a idéia moderna de higiene pode ser pensada, não parecem mais constituir a base inquestionável dos processos políticos.

A própria inteireza biológica do humano passa agora a ser um conceito questionável. Entre os achados do Projeto Genoma Humano temos a estranha constatação de que, ao longo de milênios, incorporamos em nosso patrimônio genético seqüências genéticas inteiras de bactérias. Em um sentido mais estrito: a recombinação genética promovida pela biologia molecular aponta numa direção que, se não contradiz politicamente a noção de inteireza plástica dos corpos, não depende tecnicamente desse artifício para transformar o mundo orgânico. Diferentemente do cenário descrito por Foucault, já não se trata prioritariamente de tornar os corpos mais potentes, ágeis, eficientes, disciplinados, mas de construir novos seres a partir de informações moleculares. Diante das possibilidades que se abrem com a fabricação de órgãos, tecidos a partir de células-tronco, poucos hoje teriam a ilusão de que a produção de corpos dóceis seja a essência tecnológica da biologia molecular.

A recombinação genética parece indicar não apenas a fragmentação e a instrumentalização do mundo natural, mas também a indiferenciação de fronteiras que antes eram tidas como culturalmente sagradas, tais como aquelas que delimitam o campo do humano, do corpo animal ou do vegetal (Ferreira e Ventura, 2000). Todo um discurso sociológico acerca do organismo cibernético já adianta em alguma medida este novo contexto. Algo mais radical do que a idéia de hibridação está em jogo quando uma seqüência genética humana é utilizada para promover o crescimento de cobaias ou vegetais em laboratórios. Já não se trata de pensar o corpo de próteses, a comunicação entre o orgânico e o mecânico. Uma lógica política diferenciada vem se instaurando quando se passa a conceber a totalidade da própria natureza como um espaço de transitividade virtualmente perfeita. Algo novo existe em conceber o mundo natural a partir de um alfabeto de bases nitrogenadas, ou seja, a partir de instruções moleculares que expressariam a totalidade da vida tal como a conhecemos ou possamos conhecer. Entender as regras dessa produção significa aceitar uma linguagem elementar a partir da qual, em princípio, seria possível a perfeita troca de informações genéticas entre os seres.

Algumas questões podem sinalizar as dificuldades culturais que esse novo horizonte tecnológico impõe. Diante do que convencionamos entender como mundo natural, que status teria um ser cuja memória biológica foi fabricada pela indústria farmacêutica? Distintamente da definição aristotélica de natureza, deparamo-nos agora com uma estrutura viva que não tem mais em si o seu princípio de produção. A natureza já não pode ser pensada como o outro da cultura. Que novos pressupostos políticos e culturais são forjados com a abertura deste aparente paradoxo, nomeadamente, a produção de memória?

A memória biológica já não é percebida como elemento por meio do qual a autoprodução do mundo natural se realiza, mas como dado de partida de uma produção cujos principios se situam agora no mundo sociotécnico. A memória biológica passa a ser pensada a partir da lógica informacional, do armazenamento de informação em um ou vários bancos de dados interligados. Se dermos crédito às observações da epígrafe que abre este texto, não seria uma questão menor considerar o suporte em que uma dada inscrição é registrada para sua futura recuperação e reprodução. A parábola socrática propõe que haveria 
dois caminhos básicos a seguir. O registro de uma informação poderia se realizar de modo imediato em nossa mente, sem auxílio aparente de qualquer prótese; ou ainda, alternativamente e em benefício da exatidão e do acúmulo de informação, poderíamos outorgar essa responsabilidade à escrita. Realizar essa diferenciação permitiria escolher entre, de um lado, um saber legítimo capaz de manifestar-se como presença de um logos fundador e, de outro, a aparência de instrução e sabedoria, o discurso pronto, a citação ostentatória, órfã daquele logos. A partir desse tipo de abordagem, e da necessidade de submeter memória e escrita à lógica de recuperação de um momento fundador, a metafísica ocidental concebeu de modo recorrente a legitimidade de sua verdade. Boa memória seria aquela que reproduz a verdade, a presença de tal origem. Para Platão, a sabedoria seria a capacidade de despertar por si só, de modo autônomo, a memória do verdadeiro e não a capacidade de tirar da manga a letra morta, o discurso pronto. E isto só seria possível se os limites entre o mundo humano (ou do logos), técnico e natural pudessem ser preservados.

Certamente a sociedade de informação pode ainda aprender algo com Platão acerca da relação entre quantidade de informação e sabedoria. Não obstante, uma peculiaridade chama nossa atenção para esse novo contexto sociotécnico. A ação técnica promovida pela biotecnologia molecular não se restringe a reproduzir a memória natural. Pelo contrário, ela almeja criar, produzir um novo mundo vivo. Sócrates pôde ironizar o discurso pronto, a resposta enrijecida, a traição ao contexto promovida pela escrita. A escrita biotecnológica, todavia, não é uma receita, mas a linguagem com a qual incontáveis receitas podem ser escritas. O mapeamento de um genoma abriria, não a planta da vida, mas a sintaxe da vida. Aquilo que era considerado um mundo à parte - a memória biológica das espécies, o mundo não-natural e não-técnico, com sua dinâmica autopoiética - é agora visto como um texto entre muitos outros passíveis de serem escritos. A memória natural aqui é interpretada, lida, apenas para ser reescrita, editada, revista e, eventualmente, esquecida pelo desuso em algum não-lugar de um banco de dados. Quantos bestsellers, quanta literatura descartável estaríamos dispostos a publicar e consumir neste novo mercado editorial? Quantos erros de ortografia, concordância, quanto mau gosto estilístico estaríamos dispostos a suportar para que surgisse uma "obraprima" questionável? Digamos inicialmente o seguinte: o livro da vida de que fala a biologia molecular não constitui um texto convencional, mas um hipertexto, em que tudo se conecta, todos os viventes se citam. Por isso mesmo, ele não pode nos retornar identidades circunscritas, corpos bem delimitados, lugares simbolicamente delimitados para os viventes. Isso é de fato surpreendente se, como Bernard Stiegler (1996, p. 16), considerarmos que "todo suplemento é técnico e toda técnica suplementar é um suporte de memória "que exterioriza' um programa". Todo suporte de memória, portanto, "todo arquivo [...] é ao mesmo tempo instituidor e conservador" (Derrida, 2001, p. 17). Se isso é verdade, poderíamos afirmar legitimamente que o arquivo biotecnológico procuraria conservar algo sob a dinâmica da metástase que ele promove. Deveríamos concluir muito simplesmente que na errância da técnica o logos é uma vez mais afirmado? Afinal, em todo caso, o conhecimento científico se pretende detentor de uma chave-mestra com a qual o mundo vivo em sua totalidade seria aberto.

Questões como as relações entre escritura e tecnologia, escritura e memória (biológica e cultural), escritura e tempo, requerem hoje atenção. Por esse motivo, é necessário investigar o significado da escrita e da memória, e especificamente da escrita e da memória biotecnológica, na estruturação das estratégias políticas postas em curso por meio das técnicas de recombinação genética. O terreno em que se define esse esforço é conceitual, pois acredito ser grande a necessidade de se desenvolver mecanismos teóricos para enfrentar um cenário cultural potencialmente novo.

\section{Escrita e memória}

Toda memória mobiliza um suporte e, como tal, é inconcebível sem que percebamos o quanto é porosa a fronteira entre sua dimensão externa e interna, entre sua inscrição exterior, em pa- 
piro, em livro, obra de arte, objeto e sua inscrição interna, mental. Os códigos que permitem um ou outro tipo de inscrição são abertos pela tradição. Aquilo que se nos apresenta como "árvore", "explosão", "morte", quer o percebamos ou não, já é um retorno; todo presente é um legado de uma linguagem inequivocamente pública. O exercício de uma memória não protética, puramente mental, é um absurdo quando consideramos sua formação no terreno de uma linguagem que é sempre técnica, externa. Nossa memória mais íntima e privada inscreve-se em nossa consciência com o auxílio dessa dimensão partilhada e pretérita da vida em sociedade, cujo legado nos abre, mas não determina o horizonte de nossa finitude.

Isso que parece evidente se torna mais controverso quando passamos a refletir acerca da relação entre memória e escrita. Para Derrida, a metafísica ocidental estruturou-se a partir de uma certa depreciação da palavra escrita quando confrontada com a palavra falada. Enquanto a voz traria sempre de volta a presença do logos vivo, a palavra escrita recuperaria apenas o fantasma, o simulacro daquela presença. Segundo esta tradição, a escrita seria órfã de um logos fundador, o qual nunca estaria verdadeiramente disponível para resgatá-la, tornála capaz de responder às demandas específicas do presente. Isto posto, fica fácil concluir que o domínio da escrita seria marcado por uma gradação de legitimidade: a escrita alfabética, ao recuperar de modo mais fiel a fala humana, seria mais civilizada do que a escrita cuneiforme, por exemplo. O privilégio do alfabeto como suporte mnemotécnico obedece à seguinte lógica: as palavras faladas seriam os símbolos de "experiências mentais" originárias, e a escrita, constituída de registros simbólicos secundários em relação à fala. A vOz estaria mais próxima do significado, mais próxima do vivo, de sua presença. Para Derrida, "o fonocentrismo funde-se com a determinação histórica do sentido do ser em geral como presença" (1994, p. 12).

Antes da invenção dos meios analógicos e digitais de registro sonoro, o som da palavra falada sempre foi evidência da presença efetiva, viva daquele que fala. O privilégio metafísico da palavra falada constrói a ilusão da presença em si do "quem", do sujeito autônomo, como se esse "quem" pudesse esquecer seus múltiplos vínculos com o domínio do "que", isto é, o mundo técnico e social (Stiegler, 1996). Segundo esta lógica, ser é estar presente. Mesmo nos casos em que parece não ser retratada como prótese imperfeita e órfã, a escrita não deixa de ser pensada segundo aqueles critérios que definiram uma apreciação antropocêntrica da técnica, ou seja, a escrita seria sempre mediação, instrumento de um logos autônomo e prioritário. Em alguns casos "escrever num sentido metafórico, a escrita natural, divina e viva, é venerada; ela se equipara em dignidade à origem do valor, à voz da consciência como lei divina, ao coração, ao sentimento, e assim por diante" (Derrida, 1994, p. 17) Em todo caso, a qualidade da escrita está sempre associada à sua capacidade de repetir, rememorar uma instância originária.

A escrita, no entanto, não é apenas um instrumento hipomnésico do logos, de um ser humano autônomo e pensante capaz de mobilizar seus instrumentos, mas a evidência de que esse logos só estrutura a si e ao seu pensar a partir do suplemento técnico. A publicidade da inscrição abre a possibilidade da memória. Por isso mesmo, aquilo que dispomos como escrita, seus possíveis lugares de inscrição, suas formas de recuperação e estruturação são elementos decisivos para compreendermos o tipo e o horizonte cultural dentro do qual atuamos e existimos. Não há, nesse aspecto, contradição entre o que nos diz Derrida e aquilo que os temores de Platão no fundo revelam.

Evidentemente, interessa-nos aqui analisar um tipo de escrita e de memória particular, nomeadamente, o tipo em que as próprias "técnicas de arquivamento, impressão, de inscrição e reprodução, de formalização, de codificação e de tradução de marcas" são objetos de racionalização (Derrida, 2001, p. 26). Em outras palavras, interessa-nos a escrita e a memória tecnocientífica, com seu campo de validade, com autoridades habilitadas para emitir juízos acerca do que pertence legitimamente ao seu campo e o que deve ficar fora. Esse tipo de memória configura o que Jacques Derrida chama de arquivo científico. Se estivermos certos em relação à suposição básica deste texto - a de que um horizonte técnico não é apenas um meio passível de ser mobilizado por um logos autônomo, mas oferece a própria possi- 
bilidade que o ser humano tem de ter acesso ao seu mundo -, entender os princípios que orientam e estruturam esse arquivamento é um investimento importante. O que poderia ser dito acerca do princípio que define politicamente inscrição, impressão e repetição nesse processo de arquivamento, ou seja, que define a memória científica? Em primeiro lugar, que "o arquivamento tanto produz quanto registra o evento" (Idem, p. 29). Em segundo lugar, e mais importante:

Não esqueçamos jamais esta distinção grega entre mneme ou anamnesis, por um lado, e hupómne$m a$, por outro. O arquivo é hipomnésico. E notemos de passagem um paradoxo decisivo [...]: se não há arquivo sem consignação em algum lugar exterior que assegure a possibilidade da memorização, da repetição, da reprodução ou da reimpressão, então lembremo-nos também que a própria repetição, a lógica da repetição, e até mesmo a compulsão à repetição, é, segundo Freud, indissociável da pulsão de morte. Portanto da destruição. Conseqüência: diretamente naquilo que permite e condiciona o arquivamento só encontraremos aquilo que expõe à destruição, introduzindo a priori o esquecimento e a arquiviolítica no coração do monumento. No próprio "saber de cor". O arquivo trabalha a priori contra si mesmo (Idem, pp. 22-23).

Muito é dito nesta passagem. Para os propósitos da reflexão que estou propondo neste texto, entretanto, cabe tentar recuperar precisamente o princípio ao mesmo tempo instaurador e conservador que define o "arquivo" biotecnológico. De acordo com Derrida, o "princípio arcôntico do arquivo é também um princípio de consignação, isto é, de reunião" (Idem, p. 14). O "princípio de consignação" da escrita biotecnológica contemporânea, ou seja, aquilo que permite reunir, agrupar e hierarquizar esta forma de produção tecnocientífica, é, a meu ver, dado pelo pensar matemático. Se isto está certo, é necessário mostrar como a definição deste arquivo e da lógica matemática que o legitima induz ao esquecimento de sua violência instauradora e o modo pelo qual este esquecimento constitui uma força arquiviolítica.

A importância da matemática no desenvolvimento do raciocínio científico moderno constitui um tema abundantemente explorado. Qual seria, por exemplo, o fundamento da crítica bergsoniana ao pensamento de Kant senão a reprovação de que a filosofia pudesse aceitar de modo irrefletido a matemática como base do conhecimento científico? Em seu ensaio "A filosofia e a crise do homem europeu”, Husserl (1965) já não nos fala da idealização matemática como fundamento da ciência moderna? Sob a influência dessa observação, Adorno e Horkheimer escreverão no final da Segunda Guerra Mundial:

Quando, no procedimento matemático, o desconhecido se torna incógnita de uma equação, ele se vê caracterizado por isso mesmo como algo de há muito conhecido, antes mesmo que se introduza seu valor. A natureza é, antes e depois da teoria quântica, o que deve ser apreendido matematicamente. Até aquilo que não se deixa compreender, a indissolubilidade e a irracionalidade, é cercado por teoremas matemáticos (1985, p. 37).

Antes mesmo dos recentes desenvolvimentos nas ciências biológicas, não pode causar estranheza que a ciência tenha passado a perceber a vida de modo matemático. Há, todavia, algo historicamente específico em afirmar a matemática como princípio arcôntico da biologia molecular. Primeiro, o grande impulso obtido por essa área de conhecimento a partir da década de 1950 deve-se, sem dúvida, à incorporação da matemática à sua estratégia de pesquisa. O exemplo óbvio e bem conhecido é o fato de a estrutura helicoidal do DNA só ter sido descoberta por Watson e Crick graças ao auxílio da matemática. Segundo, o próprio fato de a dinâmica natural passar a ser pensada como informacional, ou seja, a influência da cibernética no tratamento de assuntos da biologia, demandou esse tipo de tratamento.

A importância da matemática na estruturação das ciências da natureza constitui o dado de partida a partir do qual poderemos chegar a um tipo de percepção que nos toca mais diretamente, ou seja, a natureza como expressão de um programa informacional. Observemos o que Derrida tem a dizer acerca da escrita matemática:

Dentro das culturas praticantes da chamada escrita fonética, a matemática não é apenas um encla- 
ve. Isso é mencionado por todos os historiadores da escrita; eles lembram ao mesmo tempo as imperfeições da escrita alfabética, que por muito tempo passou como a escrita mais conveniente e "inteligente". Esse enclave também é o lugar onde a prática da linguagem científica desafia intrinsecamente e com uma profundidade cada vez maior o ideal da escrita fonética e toda a sua metafísica (a própria metafísica) (1994, p. 10).

Esse desafio reside no fato de que a escrita matemática não derivaria sua importância do grau de fidedignidade com o qual recupera a palavra falada; sua relação com o logos é qualitativamente diferenciada da escrita fonocêntrica, pois não requer sequer uma articulação segundo a lógica linear de uma narrativa. Em compensação, essa relação, em princípio, radicalizaria o projeto logocêntrico em seu afã instrumentalizador porque por meio da escrita matemática tem-se a sensação de poder mobilizar a totalidade dos objetos possíveis. Mas o que é de fato a escrita matemática?

\section{A escrita matemática}

É bem conhecida a influência da física newtoniana no surgimento de uma estratégia científica que procura conhecer as leis da natureza a partir de sua expressão matemática. Depois de Newton, abre-se a perspectiva de que o mundo biológico esteja submetido às mesmas leis mecânicas que explicam o movimento dos astros. Compartilhando dessa visão, por exemplo, Descartes escreve no Formation de l'animal:

Se se conhecesse bem todas as partes da semente de uma espécie animal em particular, por exemplo do homem, seria possível deduzir, por razões certas e matemáticas, a forma e a conformação de cada um de seus membros (apud Jacob, 1983, p. 61).

Bem visionárias foram essas palavras. Mais acima, considerávamos, a partir de Derrida, que um traço do arquivo científico seria um certo "saber de cor", conhecer de antemão aquilo que se nos apresenta. Esse traço tão caro ao arquivo, aquilo que the permite acumular, ser veloz e efi- ciente, era considerado por ele, paradoxalmente, uma força de autodestruição subjacente à configuração do próprio arquivo: "naquilo que permite e condiciona o arquivamento só encontraremos aquilo que expõe à destruição, introduzindo $a$ priori o esquecimento e a arquiviolítica no coração do monumento" (Derrida, 2001, p. 23). Essa linha de argumentação ajuda-nos a entender aquilo que Heidegger define como a essência da matemática. Para ele, antes de ser algo numérico, essa essência é dada por um conhecer as coisas de antemão:

\begin{abstract}
A mathēmata são as coisas na medida em que delas tomamos conhecimento como aquilo que já sabemos antecipadamente, o corpo como corpóreo, o caracteristicamente-planta da planta, o animalesco do animal, o caracteristicamente-coisa da coisa, e assim por diante (Heidegger, 1996, p. 275).
\end{abstract}

Mais adiante, ele observa:

\begin{abstract}
Assim, nós não a derivamos das coisas, mas, de certo modo, nós já a trazemos conosco. A partir disso podemos agora entender por que, por exemplo, o número é algo matemático. Nós vemos três cadeiras e dizemos que há três. O quê "três" é as três cadeiras não nos dizem, nem três maçãs, três gatos, nenhum outro três coisas. Antes, nós podemos contar três coisas se já soubermos "três" (Idem, p. 276).
\end{abstract}

Heidegger não aceitava que a diferença básica entre ciência moderna e pré-moderna pudesse ser radicada em diferentes apreciações acerca da importância do experimento na consolidação de um conhecimento sistemático. Trata-se antes da medida de penetração do matemático num e noutro contexto. Enquanto para a física moderna a natureza se encontra completamente unificada por esta forma antecipadora de conhecimento, para Aristóteles e toda a astronomia medieval cada corpo se esforçaria para assumir seu lugar no universo. "Em volta da terra está a água, em volta disto, o ar, e em volta disto, fogo - os quatro elementos. Quando um corpo se movimenta para um lugar, esse movimento concorda com sua natureza" (Idem, p. 284). Assim, "o tipo de movi- 
mento do corpo e sua relação com o seu lugar dependem da natureza do corpo" (Idem, p. 285). Se compararmos essa concepção com o princípio da gravitação universal dos corpos, perceberemos algo de especial sendo produzido pela "matematização" da natureza na física newtoniana: o natural se tornando uno.

Todo corpo natural é essencialmente do mesmo tipo. [...] O próprio conceito de lugar mudou: o lugar não é mais onde o corpo pertence de acordo com sua natureza, mas uma posição em relação a outras posições (Idem., p. 286)

Não apenas a física newtoniana já não procura explicar o movimento natural pela essência dos corpos, mas também sua compreensão de lugar a leva a entender esse movimento em termos de posições relativas.

Assim, a determinação do movimento desenvolve-se por algo que diz respeito a distâncias, extensões do mensurável [...]. O movimento é determinado como a quantidade de movimento e, de modo análogo, a massa é determinada como peso (Idem, pp. 287-288).

Esse princípio fundamenta o comércio absoluto entre as coisas, a possibilidade de substituição e transitividade perfeitas entre os viventes: $\mathrm{O}$ movimento só pode ser pensado em termos de posições relativas, provisórias e não-essenciais.

O matemático é baseado em uma tal reivindicação, isto é, a aplicação de uma determinação da coisa que não é derivada experimentalmente da coisa e, no entanto, situa-se na base de cada determinação das coisas, possibilitando-as e abrindo espaço para elas (Idem, p. 289).

Heidegger desenvolve aqui o que Husserl já havia dito acerca da idealização da realidade pela matemática. O projeto matemático, então, "salta sobre as coisas", determinando-as, prefigurando-as antes de as conhecer, "deduzindo-as", como diria Descartes. E, posto que esse projeto estabelece a "uniformidade de todos os corpos", ele passa a requerer uma medida universal, uniforme, ou seja, requer a medida numérica. Partindo dessa consta- tação, é possível dizer, com Merleau-Ponty, que as descobertas científicas que caracterizam o mundo moderno foram resultados desse desenvolvimento radical da idéia matemática de natureza.

Assim, foi uma concepção qualitativa do mundo que impediu Kepler de admitir a lei da gravitação universal. Faltou-lhe substituir a Natureza dividida em regiões qualitativamente distintas por uma Natureza em que o Ser é homogêneo em toda parte e sempre (Merleau-Ponty, 2000, p. 10).

A descoberta do cálculo infinitesimal e diferencial é o resultado mais ou menos óbvio de uma nova axiomática, em que a natureza passa a se situar num espaço-tempo uniforme e cuja tarefa primeira será a de buscar princípios, chaves que abram a lógica interna desse arquivo unificado. Há assim uma relação estreita entre a matemática e o caráter totalizador que assume a razão científica moderna.

A busca pela origem do mundo fenomênico, tema sobre o qual o logos buscou tradicionalmente sua legitimação, é o eixo central em torno do qual se poderá pensar acerca da influência da matemática na ciência moderna. O significado do que seja origem nesse contexto só pode ser desvelado dentro deste mundo criado, causado, que é o judaico-cristão. A percepção de uma oposição causal entre uma natureza desdobrada em um naturante e um naturado (uma causa e um efeito) é o caminho pelo qual a ciência moderna procurará no conjunto das evidências sensíveis princípios primeiros. "O sentido refugia-se no naturante; o naturado torna-se produto, pura exterioridade" (Merleau-Ponty, 2000, p. 10). Do mesmo modo que um dia o pensamento ocidental procurou um ser causador de todo o real, procurará agora o mecanismo irrevogável e inapelável que determina o funcionamento da natureza em sua totalidade, ou seja, procurará a lei. Esta nova prioridade, que impele o projeto matemático em direção às suas conseqüências mais radicais, determina em Descartes os limites dos quais a ação do próprio Deus Criador não poderia deixar de respeitar: "mesmo que Deus houvesse criado muitos mundos, não poderia haver nenhum onde elas [as leis da natu- 
reza] deixassem de ser observadas" (apud Merleau-Ponty, 2000, p. 12)

A natureza é um grande relógio, um grande mecanismo, cujo funcionamento pode ser categoricamente reconstituído por meio da matemática. De Descartes até o pensamento cibernético, é precisamente o prefigurar matemático, seu caráter abstrato, causal e universalista, que fundará a compreensão mecanicista do mundo natural. Para Descartes, cada ser vivo como tal, em seu funcionamento natural, não passava de um autômato. Radicalizando este tom, até o ponto em que se possa pensar o próprio cérebro como máquina de pensamento, W. Ross Ashby afirmará:

Todo movimento corporal pode ser especificado por coordenadas. Todo movimento conjugado pode ser especificado por ângulos. Tensões musculares podem ser especificadas por sua tração em dynes. Movimentos musculares podem ser especificados por coordenadas baseadas na estrutura óssea ou em algum ponto externo e fixo, podendo assim ser registrados numericamente (1960, p. 30).

Algo diferencia a especificação do pensamento matemático numa biologia de base mecanicista, que se impõe no capitalismo industrial, e a biologia molecular, de base informacional, cibernética. Esta é a diferença entre esquadrinhar e maximizar a potência de um corpo já existente e conceber o próprio corpo como atualização contingente de uma matriz informacional. No primeiro caso, o corpo individual, ou o corpo da espécie, é um dado de partida; trata-se de conhecer seu funcionamento mecânico para discipliná-lo, potencializá-lo. No segundo caso, a informação molecular, o gene, é o dado de partida, e a unidade do corpo é apenas uma contingência. A especificidade das técnicas de recombinação genética diz respeito ao status da memória. A característica central desse processo é a produção de memória biológica e não mais a suplementação técnica dessa memória através de próteses, ou a seleção artificial e limitada de determinados padrões genéticos produzidos pelas espécies.

\section{Escrevendo a vida}

Quando refletimos acerca do significado de conceber a vida como expressão da informação somos remetidos necessariamente para um campo de conhecimento bastante específico. Digamos, pois, algo sobre esta forma consumada do pensamento científico moderno - a cibernética. Seu problema central é garantir a comunicação entre elementos instrumentais e humanos mobilizados na consecução de uma tarefa qualquer. Essa comunicação articularia uma compreensão de linguagem e escrita que não circunscreve uma comunidade de humanos.

Consideramos habitualmente a comunicação e a linguagem como dirigidas de pessoa a pessoa. No entanto, é muito possível a uma pessoa falar com uma máquina, e a uma máquina falar com uma pessoa ou outra máquina (Wiener, 1954, p. 75).

Como ciência da comunicação, a cibernética não pode deixar de pensar a essência da linguagem: a linguagem é instrumento da ação, da realização de tarefas. É esta visão antropocêntrica da linguagem que levará a cibernética a negar que outros animais, exceto o ser humano, possam "construir" uma linguagem - embora sustentando a existência de uma comunicação entre estes últimos e as máquinas.

Pode parecer curioso ao leitor admitirmos máquinas ao campo da linguagem e, no entanto, negarmos quase totalmente linguagem às formigas. Todavia, ao construir máquinas, é-nos amiúde muito importante estender até elas certos atributos humanos que não são encontrados entre os membros inferiores da comunidade animal (Wiener, 1954, p. 76).

O mundo da linguagem é o mundo do agir humano, do esquecimento da morte, da entropia, na ação eficiente.

Voltemos ao ponto. Para que ela se torne uma executora de tarefas inequivocamente preestabelecidas, a essência da linguagem é estabelecida de antemão e, nesse sentido, torna-se matemática: informar para que, mediante um processo de 
retroalimentação contínua, o logos possa comandar e controlar a realização de objetivos. Uma compreensão da linguagem totalmente a serviço do operar, da instrumentalização de todas as coisas, inclusive da própria vida, tal é o grande feito da cibernética. Por isso mesmo, esta linguagem já não determina necessariamente o registro de sons humanos, o eco da palavra falada ou passível de ser enunciada como sua forma protética mais acabada. Trata-se, antes, de conceber uma escrita inequívoca. Trata-se de informar para controlar. Seu compromisso é, pois, antes com a velocidade e efetividade da execução do que com o pensar. Se em sua definição do que seja linguagem a cibernética pôde estender até às máquinas "atributos humanos", isto só foi possível porque em grande medida a comunicação tipicamente humana, a linguagem, foi também reduzida à ação instrumental. Sob essa perspectiva, não pode causar espanto que o mundo biológico possa ser compreendido como expressão de um programa (com uma dada linguagem e uma determinada sintaxe) que, sob vários aspectos, é paradigmático para as próprias ciências da informação. Não obstante, permanece o fato de que formigas não possam ser consideradas operadoras de uma comunicação do tipo lingüístico. A relação entre o logos e o mundo natural permanece ambígua na cibernética: a linguagem tanto é aquilo que permitirá dissolver as fronteiras existentes entre o humano, o natural e o técnico, como deve constituir-se em elemento diferenciador capaz de colocar o humano a salvo dessa dissolução. E esta é a tensão com a qual viemos lidando: em que medida o logos ainda pode controlar os princípios arquívicos que a escrita matemática determina?

Ora, quer do ponto de vista da utilização eficiente de energia, da eliminação de possíveis erros de transmissão de mensagens, ou da efetividade das ações que determina, a expressão de instruções genéticas deve ser considerada um processo de comunicação extremamente sofisticado e bem-sucedido. O DNA instrui o RNA que, por sua vez, se encarrega de transmitir mensagens que resultarão na síntese de proteínas necessárias à formação e ao funcionamento do corpo. Na medida em que a natureza é compreendida como um pro- grama informacional e, por meio da ação técnica, submetida à lógica da cultura, poderíamos dizer que o obstáculo que nos impedia de percebê-la como linguagem já não existe. A natureza já não é o outro da cultura. O mundo biológico e o mundo da cultura foram reduzidos à dinâmica informacional. Talvez por isso já seja possível para Nobert Wiener (1954, p. 95), em 1950, dizer algo como: "Não passamos de remoinhos num rio de água sempre a correr. Não somos material que subsista, mas padrões que se perpetuam a si próprios" (Wiener, 1954, p. 95). Essa desmaterialização da vida é um elemento importante da nova dinâmica biopolítica que se abre com a biologia molecular. Por esse motivo será possível para os teóricos da sociobiologia considerarem que nada mais somos que naves, barcos contingentes onde navegam e se perpetuam os genes.

Mas o que exatamente Wiener tem em mente quando diz que a vida humana é um "padrão que se perpetua"? Ele mesmo nos responde: "Um padrão é uma mensagem e pode ser transmitido como tal" (Idem, ibidem). Se bem que tendo em mente algo mais próximo ao terreno da ficção científica, como a possibilidade de teletransportação, ele já depunha acerca de uma nova concepção de vida; a vida como atualização de informações escritas nesta língua fundamental:

[...] o fato de não podermos telegrafar, de um lugar para outro, o padrão de um homem, parece dever-se a dificuldades técnicas, e, em especial, à dificuldade de manter um organismo em existência durante tal radical reconstrução. [...] Quanto ao problema da reconstrução radical do organismo vivo, seria difícil descobrir qualquer reconstrução dessa espécie que fosse mais radical que a de uma borboleta durante o seu período de crisálida" (Idem, p. 102).

Quando, a partir de sua influência, a biologia passa a falar de uma linguagem e uma escritura da vida, a principal dificuldade para o cientista social é perceber que esse entendimento de língua e escrita, embora ainda enredados em metafísica de presença, na possibilidade de determinar um logos original que tudo subordina, age contra a tradição fônica do mundo ocidental e con- 
tra aquilo que essa tradição oferece como sendo a essência do humano. O humano nesse discurso não se perde em próteses que o reconfiguram, mas em não poder mais opor o mundo natural ao da cultura. Os programas da vida já não precisam falar de uma origem e de seu esquecimento. Isso significa, entre outras coisas, que tal escrita não precisa se estruturar a partir da compreensão temporal característica das narrativas fonocêntricas: começo, meio e fim.

Desde o começo do século passado percebemos em escritores como Proust a possibilidade de narrativas não lineares. No campo científico, a narrativa psicanalítica identificou uma certa imbricação entre passado e presente. A intervenção psicanalítica procura restabelecer a possibilidade de uma narrativa ao dissolver os nós que fazem do presente repetição patológica do passado e não um momento de abertura para o novo, para o futuro. A lógica cibernética desfaz a narrativa linear da escrita fônica de um outro modo. A consecução de um futuro determinado, modificar a memória genética de uma árvore em vias de extinção de modo a torná-la resistente a pragas, por exemplo, orienta a recuperação do passado. O futuro determinado corrige o presente e o passado. Ocorre-me o caso tão divulgado pela mídia de uma mulher norte-americana que decidiu engravidar por meio de fertilização in vitro, utilizando para isso o esperma de seu marido armazenado num banco de sêmen. O marido, no entanto, estava morto. Alguns poderão argumentar que esse exemplo, como tantos outros do mesmo gênero gestações mantidas mesmo após a morte clínica da mãe biológica - não pertencem a rigor ao horizonte da biologia molecular. Chamo a atenção, todavia, para a idéia de arquivamento, do ato de pôr em reserva, como um dado importante deste horizonte técnico-cultural. O passado já não nos comove, com sua reivindicação de constituir uma instância originária e pretérita, uma chave para a leitura do presente - chave que em seu não-maisser demanda a fidelidade da memória. A linearidade da escrita anterior ao hipertexto e a experiência cultural de um tempo linear parecem se harmonizar perfeitamente. Mas, eis que estamos diante de um horizonte tecnológico em que o passado pode ser trazido de volta, e isso não apenas virtualmente como rememoração, mas de fato atualizado como contemporâneo do presente. Um exemplo ilustrativo pode ser encontrado no bioterrorismo. Em 1979, a vacinação antivaríola foi abandonada por um motivo simples, a doença foi considerada extinta. Após o atentado de 11 de setembro de 2001 nos Estados Unidos, as agências de segurança nacionais passaram a temer que a varíola pudesse retornar deixando em descoberto uma grande parte da população do globo para a qual um eventual processo de imunização seria agora ineficaz. Bactérias causadoras da varíola, peste, botulismo, antraz ressurgem para testar a capacidade de convivência de pelo menos três temporalidades distintas: um presente de perplexidade diante de uma arma de efeito retardado, um passado preservado em laboratório e uma eventual, futura, modificação genética destas bactérias que as tornem mais letais do que já o são hoje. Outro exemplo. Um dos principais problemas que a clonagem terapêutica hoje enfrenta é de ordem ética: deveríamos tratar fetos humanos de três a seis dias como se fossem simplesmente meios para a produção de tecidos ou órgãos? Uma das maneiras de evitar esse tipo de dificuldade seria dada pela perspectiva de reprogramar células adultas de modo que elas possam ser reconduzidas à sua forma embrionária, como mostra artigo de Steve Connor, publicado no jornal inglês Independent, de 17 de agosto de 2000.

O passado está arquivado e disponível - coisa surpreendente se considerarmos que o acesso à nossa própria finitude, mortalidade, acesso ao nosso ser-para-a-morte, sempre nos foi tradicionalmente dado na imagem do irremediavelmente pretérito. $\mathrm{Na}$ escrita, como na foto de nossos avós, a evidência de nossa mortalidade, a evidência de um mundo que continua, independentemente de nossa presença. O fato de a memória biológica arquivada, seus genomas e proteomas, não estar comprometida com a reprodução do mundo natural tal como ele nos foi legado desfaz em grande medida o conforto e a segurança de uma compreensão linear da história da vida. A ovelha Dolly, primeiro mamífero clonado, envelheceu mais rapidamente que sua própria "mãe". 
Podemos ainda falar de papéis centrados numa lógica de origens, como "pai" e "mãe", diante deste fato irrefutável: Dolly foi menos uma cria que um desenvolvimento celular de sua suposta "mãe"? Dolly foi a possibilidade do presente visitar um futuro possível, assim como a possibilidade do futuro desenvolver-se como algo pretérito. Se no filme Intervista, Fellini, Marcello Mastroianni e Anita Ekberg visitam o seu passado e constatam sua mortalidade (Stiegler, 1996), no envelhecimento precoce da ovelha Dolly, o presente tem a possibilidade de visitar seu futuro biológico, e este futuro teria a oportunidade de reconhecer o passado como algo que lhe sobreviverá.

A perspectiva de produção de memória biológica requer uma compreensão matemática da natureza por um motivo simples: primeiro, ela pressupõe a perfeita transitividade entre os viventes. Agora percebemos que essa transitividade se opera também num campo temporal. Da linearidade das narrativas de progresso do capitalismo industrial passamos ao tempo matricial dos fluxos de informação. Apenas uma natureza unificada pode ser objeto de uma ação tecnológica capaz de reunir traços genéticos de seres aparentemente tão distantes quanto algas e macacos.

Como entender o espanto que organismos geneticamente modificados, como a Dolly, tendem a suscitar? Creio que essa surpresa decorre do fato de ainda nos localizarmos dentro de um horizonte cultural no qual a inteireza dos corpos, sua materialidade e a possibilidade de delimitação visual clara, ainda constitui um fator orientador para o modo de produção capitalista. Entre os séculos XVII e XIX, o capitalismo pôde conceber o corpo escravo como um instrumento produtivo e de reprodução. Apenas dentro deste novo horizonte técnico-cultural, entretanto, a vida pode ser pensa$d a$, de modo genérico, como produto. A escritura matemática da biologia molecular, assim, propõe novas formas de enunciar nossa relação com a vida. Em um artigo de $1^{\circ}$ de novembro de 2001, lia-se na Folha de São Paulo o seguinte título de matéria: "USP lança animal transgênico no Brasil". A partir de quais pressupostos podemos pensar no "lançamento" (comercial ou não) de um animal? Mais adiante, no corpo da matéria, lemos: "Chris- tian, camundongo que nasceu em julho, foi fruto do trabalho de três anos do grupo coordenado pela pesquisadora Lygia Veiga Pereira”.

Para a biologia molecular a inteireza corpórea dos seres é apenas um espaço onde a informação genética se torna passível de arquivamento e modificação. Um exemplo contundente dessa forma de pensar a vida pode ser percebido na atitude que, para muitos, orienta iniciativas científicas como o Projeto da Diversidade do Genoma Humano. Capitaneado pelo professor Luigi Luca Cavalli-Sforza, geneticista da Universidade de Stanford na Califórnia, este projeto tem por fim seqüenciar e arquivar o genoma de grupos étnicos com patrimônio genético raro - patrimônio hoje ameaçado por constantes movimentos migratórios. Muitos desses grupos resistiram ao projeto com base num argumento simples: o único interesse do PDGH era o de arquivar, preservar um patrimônio genético potencialmente lucrativo, pouca importância sendo atribuída à questão premente da preservação, sobrevivência, concreta desses grupos. A biologia molecular percebe o corpo da mesma forma que o pensamento neoliberal percebe o funcionamento das economias nacionais. Embora tanto o corpo como a nação possam continuar existindo, o poder que sobre eles se instaura num e noutro caso é impessoal, descorporificado (disembodied) e, na medida em que o princípio de seu modus operandi é o livre fluxo entre fronteiras, esse poder tem pretensões totais.

A tecnociência hoje trabalha para detectar uma origem não viva da vida, a instrução já escrita capaz de produzir o vivente. Uma escrita e uma memória não originariamente humanas, uma escrita "a serviço" da feitura da vida, inclusive da vida humana. Ao menos duas possibilidades técnicas se apresentam nesse contexto. O pensamento antropocêntrico parece se fortalecer quando nos é oferecida como alternativa inevitável a apropriação instrumental desta escrita, que já não pode mais ser compreendida apenas como mnemotécnica da cultura. Independentemente do fato de hoje nos percebermos como partes integrantes da escritura de uma vida terrestre, "lançamos" animais transgênicos, como lançaríamos uma nova marca de roupa íntima - afinal, para alguns, pro- 
duzir alimentos geneticamente modificados é apenas mais uma opção comercial. Produzimos a vida e a vida nos escapa. Escapa em conseqüências não previsíveis da ação técnica. Escapa porque a vida, reduzida a uma operação, fica esvaziada de significado. Uma tal reinstauração do pensamento antropocêntrico, todavia, radicaliza uma ambigüidade profunda do pensamento ocidental - tenhamos sempre em mente que a matéria e os instrumentos sobre o qual o logos supostamente se debruça são errantes. Como realizar uma apropriação logocêntrica, instrumental, das instruções responsáveis, entre outras coisas, por nossa "configuração vital" quando percebemos, de partida, que o texto da vida é um hipertexto?

O hipertexto, mais que nenhum outro tipo de escrita, é errância e vocação para o mundo. Por isso, a estrutura mnemotécnica da escrita da vida, sua hipertextualidade, já não pode oferecer a originariedade, a força do pai como força legitimadora do logos, nem o tipo de narrativa a ele associado. A força arquívica deste logos, da digitalização da vida que ele promove, reside na sua ambição de tudo incluir - o que significa dizer que em sua dinâmica totalizante ele se estrutura como pulsão de destruição do próprio arquivo. ${ }^{1}$ Vem-me à lembrança o estranho caso de "Funes, o memorioso" que, por ter desenvolvido a prodigiosa capacidade de tudo arquivar em sua memória, vê-se privado da possibilidade epistemológica e política de verdadeiramente conhecer. Seria uma pena, todavia, concluir este artigo em termos tão neokantianos, ou seja, sugerindo que apenas por estarmos largados na coisa em si do universo ou dos arquivos biotecnológicos, teríamos perdido a capacidade de ativamente conhecer e de definir, ou ter acesso a, princípios políticos claros de arquivamento. Em vez disso, concluiríamos elaborando duas questões acerca das inquietações políticas que resultam desse contexto de transformações profundas: deveríamos, diante de tudo que foi exposto, tomar como ponto de partida a possibilidade de redefinir um lugar, garantias mínimas, em meio ao não-lugar dos arquivos da vida ou aceitar como inevitável a sua dinâmica errante como um ponto de partida para nossos esforços políticos? E, assim, estamos de volta a Platão. O problema para o cientista social é tentar entender um princípio de arquivamento que não mais depende da idéia de origem e perceber que, embora não se oriente por meio de uma lógica fundacionalista, pois o matemático não necessita desta centralidade para operar, a nova realidade tecnocientífica ainda promove o logos. Mas hoje esse logos é condição de enunciação exatamente do quê, se aceitarmos que ele já não pode mais enunciar de modo coerente a presença?

\section{NOTAS}

1 A força totalizadora do arquivo biotecnológico talvez possa ser ilustrada pela dificuldade de se lhe fazer oposição em bases racionais. "Houve na França experiências com milho que foram objeto de cólera de certos ecologistas suíços e alemães; parece que foram destruir essas experiências de Colmar, mas que aniquilaram no local recursos raros cuja proteção eles geralmente preconizam... Considerando que nada estava rotulado, eles se enganaram. $\mathrm{Na}$ verdade, entende-se ao mesmo tempo mal e bem esse ecoterrorismo: mal, porque as experiências feitas até agora ainda não foram nocivas; bem, porque se essas pessoas querem lutar contra riscos biotecnológicos, duvido que lhes dêem meios de fazê-lo com inteligência" (Marie Angèle-Hermitte em entrevista a Ruth Scheps, 1996, pp. 87-88).

\section{BIBLIOGRAFIA}

ADORNO, T. \& HORKHEIMER, Max. (1985), Dialética do esclarecimento. Rio de Janeiro, Jorge Zahar.

ASHBY, W. Ross. (1960), Design for a Brain: the origin of adaptative behaviour. Nova York, John Wiley \& Sons.

DERRIDA, Jacques. (1993), Writing and difference. Londres, Routledge.

(1994), Of grammatology. Londres, John Hopkins University Press.

(1997), A farmácia de Platão. São Paulo, Iluminuras. 
. (2001), Mal de arquivo: uma impressão freudiana. Rio de Janeiro, RelumeDumará.

FERREIRA, Jonatas. (2002), "O alfabeto da vida: da reprodução à produção". Lua Nova, 55-56: 219-240.

FERREIRA, Jonatas \& VENTURA, Jorge. (2000), "O monstruoso tecnológico". Perspectivas, Revista de Ciências Sociais, 23: 25-50, Unesp.

HEIDEGGER, Martin. (1996), Basic writings. Londres, Routledge.

. (1999), Língua de tradição e lingua técnica. Lisboa, Passagens.

HUSSERL, Edmund. (1965): Philosophy and the crisis of philosophy. Nova York, Harper \& Row.

JACOB, François. (1983), A lógica da vida: uma bistória da hereditaridedade. Rio de Janeiro, Graal.
LAQUEUR, Thomas. (2001), Inventando o sexo: corpo e gênero dos gregos a Freud. Rio de Janeiro, Relume-Dumará.

MERLEAU-PONTY, Maurice. (2000), A natureza. São Paulo, Martins Fontes.

SCHEPS, Ruth. (1996), O império das técnicas. São Paulo, Papirus.

STIEGLER, Bernard. (1996), La technique et le temps. Paris, Galitée (vol. 2: La désorientation).

WIENER, Nobert. (1971), Cibernetics or control and communication in the animal and the machine. Cambridge, Massachussets, MIT Press.

(1954), Cibernética e sociedade: o uso bumano de seres bumanos. São Paulo, Cultrix. 


\section{A PRODUÇÃo dE MEMÓRIA BIOTECNOLÓGICA E SUAS CONSEQÜÊNCIAS CULTURAIS}

\author{
Jonatas Ferreira
}

\section{Palavras-chave}

Biotecnologia; Cibernética; Natureza; Memória; Vida

A memória biológica foi tradicionalmente concebida como escrita sagrada, cuja sintaxe estaria vedada ao ser humano - ele próprio produto da palavra divina. A partir dos avanços recentes da biologia molecular, no entanto, essa sintaxe e essa escrita estariam sendo desveladas e apropriadas pela tecnociência. Este artigo investiga a relação entre a digitalização da vida e a lógica matemática que determina a dinâmica interna desta forma de escritura. Ao estabelecer uma relação fundamental entre matemática e ciência moderna, especialmente a maneira pela qual ela aparece na cibernética e na biologia molecular, o autor procura identificar o impacto que o arquivamento e a edição da vida podem ter na cultura ocidental.

\section{THE PRODUCTION OF BIOTECHNOLOGICAL MEMORY AND ITS CULTURAL CONSEQUENCES}

Jonatas Ferreira

Key words

Biotechnology; Cybernetic; Nature; Memory; Life

Biologic memory has traditionally been conceived as a sacred writing, whose syntax would be forever barred to the human being - he himself a product of Divine Word. Given the recent advances in molecular biology, however, such syntax and writing have been unveiled and appropriated by tecnoscience. This paper investigates the relationship between the digitalization of life and the mathematical logics that determines the inner dynamics of this kind of scripture. Aiming at establishing the fundamental relationship between mathematics and modern science, particularly as it emerges in cybernetics and molecular biology, the article seeks to identify the impact the archiving and edition of life might have in the Western Culture.

\section{LA PRODUCTION DE LA MÉMOIRE BIOTECH- NOLOGIQUE ET SES CON- SÉQUENCES CULTURELLES}

\author{
Jonatas Ferreira
}

\author{
Mots-clés \\ Biotechnologie; Cybernétique; \\ Nature; Mémoire; Vie.
}

La mémoire biologique a été traditionnellement conçue en tant qu'écriture sacrée dont la syntaxe serait interdite à l'être humain - luimême le produit de la parole divine. À partir des récentes avancées de la biologie moléculaire, cette syntaxe et cette écriture seraient, néanmoins, entrain d'être dévoilées et appropriées par la technoscience. Cet article recherche le rapport entre la numérisation de la vie et la logique mathématique qui détermine la dynamique interne de cette forme d'écriture. En établissant une relation fondamentale entre la mathématique et la science moderne, spécialement la manière par laquelle elle apparaît dans la cybernétique et dans la biologie moléculaire, l'auteur cherche à identifier l'impact que l'archivage et l'édition de la vie peuvent produire dans la culture occidentale. 